\title{
New records of lichens and allied fungi from the Leningrad Region, Russia. XI
}

\author{
Dmitry E. Himelbrant ${ }^{1,2}$, Irina S. Stepanchikova ${ }^{1,2}$, Sergey V. Chesnokov', \\ Liudmila A. Konoreva ${ }^{2,3}$, Agata A. Rodionova ${ }^{1,2}$, Ekaterina S. Kuznetsova ${ }^{1,2} \&$ \\ Ulf Schiefelbein ${ }^{4}$ \\ ${ }^{1}$ Department of Botany, St. Petersburg State University, Universitetskaya emb. 7-9, 199034 St. Petersburg, Russia. \\ E-mails: d_brant@mail.ru, stepa_ir@mail.ru, lyn.alvashak@gmail.com, igel_kuzn@mail.ru \\ ${ }^{2}$ Laboratory of Lichenology and Bryology, Komarov Botanical Institute RAS, Professor Popov St. 2, \\ 197376 St. Petersburg, Russia. E-mail: lukinbrat@mail.ru \\ ${ }^{3}$ Polar-alpine Botanical Garden-Institute, 184250 Murmansk Region, Kirovsk, Russia. E-mail: ajdarzapov@yandex.ru \\ ${ }^{4}$ Rostock University, Botanical Garden, Schwaansche Straße 2, 18055 Rostock, Germany. \\ E-mail: ulf.schiefelbein@uni-rostock.de
}

\begin{abstract}
Twelve lichen species and two lichenicolous fungi, of them seven that belong to Micarea prasina group, are reported for the first time for St. Petersburg or the whole Leningrad Region. The lichenicolous fungus Intralichen baccisporus is new to Russia, and the lichen Micarea nowakii - for European Russia. A comparative table of characteristics for seven species of Micarea prasina group is presented.
\end{abstract}

Keywords: lichen diversity, Konevets, Moschny, Tuters

\section{INTRODUCTION}

The project on lichen inventory in St. Petersburg and Leningrad Region started at the end of $20^{\text {th }}$ century (Musyakova \& Himelbrant, 1998). Its main object is comprehensive regional study of the diversity, ecology of lichens and allied fungi, and their use in nature conservation. In this article we continue to publish new and noteworthy records on lichens and allied fungi from the Leningrad Region and St. Petersburg (see e.g., Stepanchikova et al., 2010, 2018; Kuznetsova et al., 2012; Himelbrant et al., 2017, 2019). This paper is mainly dedicated to the new records of Micarea species and some other crustose lichens or lichenicolous fungi that are difficult to find and identify. Newly published records also include some additions to comprehensively studied lichen floras of the islands of Konevets (Himelbrant et al., 2018, 2019; Suija et al., 2020), Lavansaari (Stepanchikova et al., 2019), and Tuters (Stepanchikova et al., 2017; Himelbrant et al., 2019).

\section{MATERIAL AND METHODS}

The lichen specimens were mainly collected by Dmitry E. Himelbrant, Irina S. Stepanchikova, Ekaterina S. Kuznetsova, Agata A. Rodionova, Ludmila V. Gagarina, and Gulnara
Tagirdzhanova in 2015-2020 in the Leningrad Region and St. Petersburg. The specimens are deposited in the lichen herbaria of St. Petersburg State University (LECB), Komarov Botanical Institute (LE), and University of Helsinki (H). The cited specimens were identified by the authors of the paper. Chromatography was performed by Sergey V. Chesnokov and Liudmila A. Konoreva according to the standard techniques of high performance thin-layer chromatography using solvent system C (Orange et al., 2001). Additionally, we present a comparative table of characteristics (Table 1) for seven species of Micarea prasina group which are reported here, based on literature (Czarnota, 2007; Guzow-Krzemińska et al., 2016; Launis \& Myllys, 2019; Launis et al., 2019a,b; Kantelinen et al., 2021) and own observations. The photo of Sclerophora peronella in the field was taken by Irina S. Stepanchikova with Olympus Tough TG-5 camera.

The names of the main collectors in the species list are abbreviated as follows: AR - Agata A. Rodionova, DH - Dmitry E. Himelbrant, EK - Ekaterina S. Kuznetsova, IS - Irina S. Stepanchikova, and LG - Ludmila V. Gagarina. The subdivision of the Leningrad Region (LR) was published in our previous paper (Stepanchikova et al., 2010); the biogeographical border between the eastern and western parts of the region is the Volkhov 
River (see Kuznetsova et al., 2007). The following abbreviations are used here: ELR - Eastern Leningrad Region, SPb - St. Petersburg, WLR Western Leningrad Region. The biogeographical provinces of Eastern Fennoscandia are abbreviated traditionally (Kotiranta et al., 1998): Ik Isthmus karelicus, $\mathrm{Ka}$ - Karelia australis. All geographical coordinates are given in the spatial reference system WGS 1984. Lichenicolous fungi are marked with \#. The nomenclature of taxa generally follows Nordin et al. (2011), Diederich et al. (2018), and Lawrey \& Diederich (2018).

\section{RESULTS AND DISCUSSION}

Altogether 14 species are reported here, including 12 lichens and two lichenicolous fungi. Intralichen baccisporus is new to Russia, and Micarea nowakii - for European Russia. Six species (Micarea fallax, M. laeta, M. microareolata, M. pusilla, M. soralifera, M. tomentosa, and Sclerophora peronella) are new for the Leningrad Region; four species (Elixia flexella, Erythricium aurantiacum, Lepraria borealis, and Micarea adnata) are new for St. Petersburg. Parmelina tiliacea is first reliably recorded in the Leningrad Region.

Altogether 33 species of Micarea are known from the Leningrad Region and St. Petersburg now, of them 12 belong to Micarea prasina group which is actively studied last years, including 7 presented here (see the main distinguishing characters in Table 1). Nowadays 33 species of Micarea prasina group have been described worldwide, and 25 of them are known from Northern and Central Europe (Kantelinen et al., 2021). Taking in account an overall diversity and high amount of recently described species in the group, as well as the presence of suitable habitats in the Leningrad Region, we expect the regional list of Micarea prasina group to be increased in the nearest years. Three best studied and richest local lichen floras of the region are updated again: the lichen list of Konevets Island (Konevitsa) includes now 442 species, Moschny Island (Lavansaari) - 352 species, and Tuters Island (Tytärsaari) - 336 species. Ca 1150 species, including 980 lichens, 140 lichenicolous and 30 saprobic fungi, are currently recorded in the Leningrad Region and St. Petersburg.

\section{THE SPECIES}

Elixia fleXella (Ach.) Lumbsch - SPb, Kolpino District, between Ivanovskoe and Kolpino, Ust'-Tosnenskoe Bog Proposed Protected Area, $\mathrm{N}$ to electric power line, $59^{\circ} 45^{\prime} 37.1^{\prime \prime} \mathrm{N}$, $30^{\circ} 42$ '21.0"E, alt. $13 \mathrm{~m}$, pine forest with Sphagnum spp., Polytrichum sp., Eriophorum vaginatum L., and Chamaedaphne calyculata (L.) Moench, on wood of Pinus sylvestris L., 13.05.2019, IS \& DH (LECB); same place, $59^{\circ} 45^{\prime} 18.8^{\prime \prime} \mathrm{N}$, $30^{\circ} 43^{\prime} 38.2$ "E, alt. $14 \mathrm{~m}$, pine forest with Vaccinium uliginosum L., Ledum palustre L., Sphagnum spp., and Polytrichum sp., 23.05.2019, IS \& DH (LECB). - New to SPb. Distribution in North-Western European Russia outside of SPb: Republic of Karelia (Himelbrant \& Kuznetsova, 2002). Distribution in Fennoscandia and Baltic countries: Norway, Sweden, Finland (Nordin et al., 2011), and Estonia (Randlane et al., 2019). Very characteristic lignicolous lichen with indistinct thallus, narrowly elongate to angular or roundish apothecia firstly having slit-like disc and enrolled margin, hymenium I+ pale blue, asci Elixia-type, and 8 small simple hyaline spores 5-8 × 3-4.5 $\mu \mathrm{m}$ (Smith et al., 2009).

\#ERYTHRICIUM AURANTIACUM (Lasch) D. Hawksw. \& A. Henrici - SPb, Petrodvorets District, between Kikenka River and Volodarsky, Kikenka River valley $\mathrm{N}$ to railway, 59 $50^{\prime} 39.7$ ' $\mathrm{N}, 30^{\circ} 03^{\prime} 02.7$ ' $\mathrm{E}$, abandoned garden, on thallus of Physcia cf. aipolia (Ehrh. ex Humb.) Fürnr. on bark of young Quercus robur L., 09.10.2016, IS \& DH (LECB); Pushkin District, Pavlovsk, W to Michurina Str. and S to Tyz'va River, Alexandrova Dacha Park, 59 40’41.7'N, 30²5'35.9'E, linden alley and group of larches, on thallus of Xanthoria parietina (L.) Th. Fr. on bark of Tilia cordata Miller, 12.09.2017, IS \& DH (LECB). - New to $\mathrm{SPb}$, known from WLR (Stepanchikova et al., 2019). Distribution in North-Western European Russia outside of LR: not reported. Distribution in Fennoscandia and Baltic countries: Sweden (Nordin et al., 2011), Estonia (Randlane et al., 2019), Latvia (Motiejūnaitè et al., 2016), Lithuania (Motiejūnaitè, 2017).

\#InTRalichen Baccisporus D. Hawksw. \& M. S. Cole - WLR, Ka, Kingisepp District, N part of Moschny Island (former Lavansaari), Lankoori Spit, $60^{\circ} 01^{\prime} 44.8^{\prime \prime} \mathrm{N}, 27^{\circ} 48^{\prime} 44.8^{\prime \prime} \mathrm{E}$, alt. $1 \mathrm{~m}$, vicinity of old granite pier, in apothecia of Candelariella aurella (Hoffm.) Zahlbr. on granite boulder 


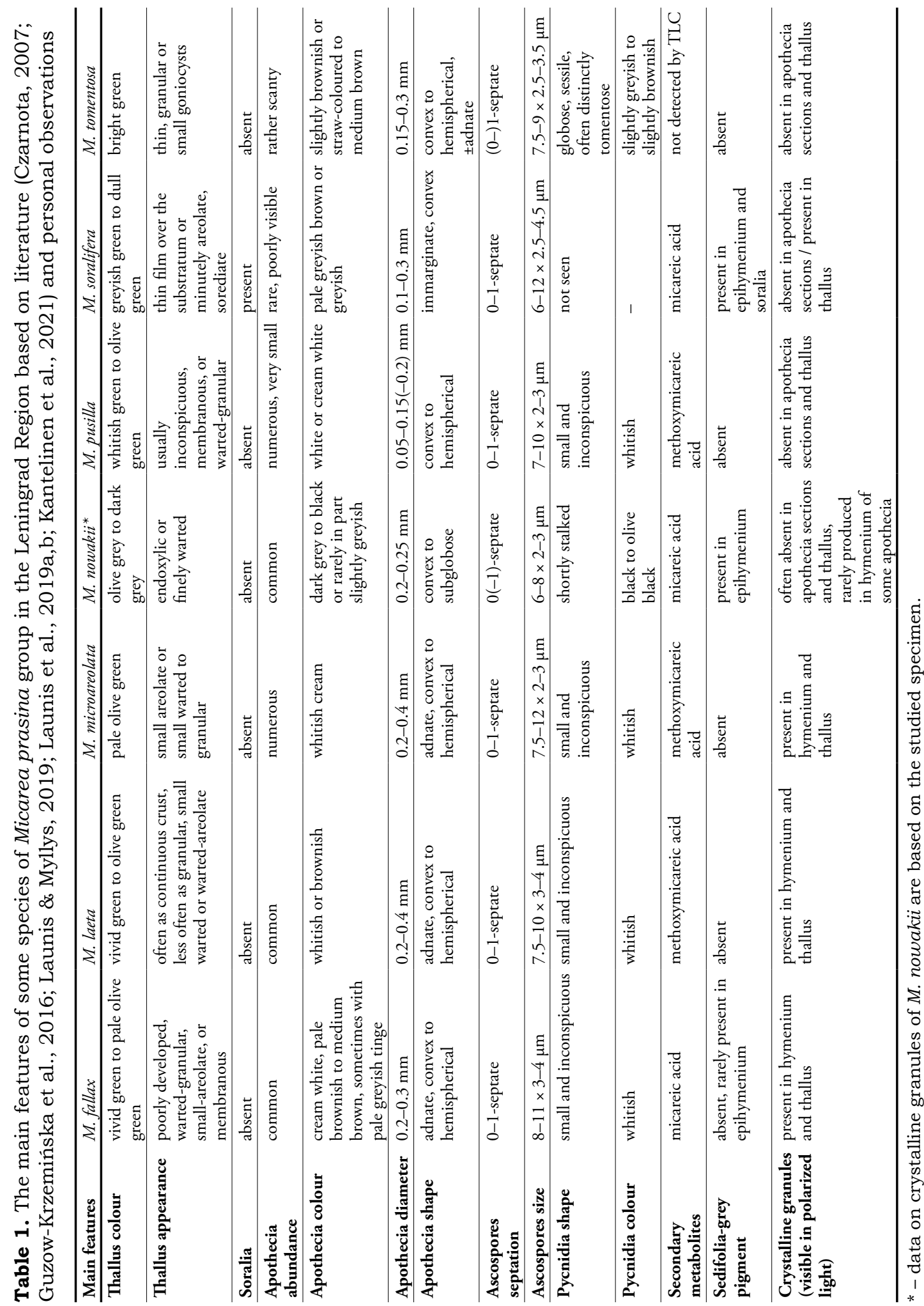


manured by birds, 15.08.2017, IS \& DH, det. U. Schiefelbein (H). - New to Russia. Distribution in Fennoscandia and Baltic countries: not reported. This rarely reported species was described from Nebraska in North America (Hawksworth \& Cole, 2002). In Europe the species is known from Austria, Belgium, Luxembourg, Netherlands (Sérusiaux et al., 2003), British Isles (Intralichen..., 2021), Germany (Brackel, 2014; Rettig, 2016), and Italy, Sicilia (Brackel, 2008). This dematiaceous hyphomycete is characterized by multicellular, subglobose aggregated conidia produced in chains, which links it to Intralichen christiansenii (D. Hawksw.) D. Hawksw. \& M. S. Cole and I. lichenicola (M. S. Christ. \& D. Hawksw.) D. Hawksw. \& M. S. Cole. However, conidia of these two species are up to 4-celled, but appear to clump together to form multicellular propagules recalling the irregularly ellipsoid conidia of $I$. baccisporus (Hawksworth \& Cole, 2002). Intralichen baccisporus occurs mainly in the hymenium of Caloplaca and Candelariella species (Sérusiaux et al., 2003; Brackel, 2014). Records from other host species need to be proved.

LEPRARIA BOREALIS Loht. \& Tønsberg - SPb, Petrodvorets District, Lomonosov, ca. $600 \mathrm{~m} \mathrm{SE}$ to Zavarina Str., 59 $54^{\prime} 50.9^{\prime \prime} \mathrm{N}, 2^{\circ} 43^{\prime} 02.2^{\prime \prime} \mathrm{E}$, pine forest with spruce and birch, with green mosses and Vaccinium myrtillus L., on granite boulder, 20.05.2015, IS \& DH (LECB); same place, between Ilikovskaya road and Oranienbaumsky prospect, vicinity to electric power line, 59 53'09.3'N, 29 45’02.6”'E, steep bank of brook in birch-pine forest, on granite boulder, 27.09.2015, IS \& DH (LECB); same place, SW to Oranienbaumsky Park, 59 $54^{\prime} 36.1^{\prime \prime} \mathrm{N}$, $29^{\circ} 43^{\prime} 48.8^{\prime \prime} \mathrm{E}$, on large granite boulder "Cherepakha”, 20.05.2015, IS \& DH (LECB). Thalli contain atranorin, jackinic/rangiformic and norjackinic/norrangiformic acids. - New to $\mathrm{SPb}$, known from ELR and WLR (Himelbrant et al., 2015; Stepanchikova et al., 2017). Distribution in North-Western European Russia outside of LR: Republic of Karelia (Kukwa et al., 2003). Distribution in Fennoscandia and Baltic countries: Norway, Sweden, Finland (Nordin et al., 2011), Estonia (Randlane et al., 2019), Lithuania (Motiejūnaitè, 2017). The species belongs to Lepraria neglecta group and is recognized by some authors as a chemotype of L. neglecta (Nyl.) Lettau. Chemically similar to Lepraria jackii
Tønsberg s. 1. which differs by having greenish to yellow-green thallus, smaller soredia (soredia up to $50 \mu \mathrm{m}$ diam. and consoredia $80 \mu \mathrm{m}$ diam. in L. jackii vs. soredia $70 \mu \mathrm{m}$ diam. and consoredia 160-200 $\mu \mathrm{m}$ diam. in L. borealis), and preference for tree bark as a substrate (Makarova \& Himelbrant, 2008).

Micarea ADNATA Coppins - SPb, Petrodvorets District, Strel'na, between Strelka River and Novye Zavody Street, 5950'02.9”N, 2959'11.4”E, pine forest with young oaks (Quercus robur) and rowan (Sorbus aucuparia L.) undergrowth, with Oxalis acetosella L., Vaccinium myrtillus, and green mosses, on bark of Pinus sylvestris, 03.06.2017, DH \& IS (LECB). - New to SPb. Distribution in North-Western European Russia outside of SPb: Republic of Karelia (Alstrup et al., 2005). Distribution in Fennoscandia and Baltic countries: Norway and Sweden (Nordin et al., 2011). Characterized by continuous, often waxy in appearance, to sometimes granular thallus, apothecia-like sporodochia, straw-coloured to brownish apothecia often with white arachnoid rim, ellipsoid 0-1-septate ascospores, and producing no lichen substances; for detailed description see Czarnota (2007).

Micarea fallaX Launis \& Myllys - WLR, Ik, Priozersk District, N part of Konevets Island, $60^{\circ} 52^{\prime} 45^{\prime \prime} \mathrm{N}, 30^{\circ} 37^{\prime} 31^{\prime \prime} \mathrm{E}$, old-growth spruce forest with Sphagnum spp. and dwarf shrubs, on wood of Picea abies (L.) H. Karst. (log), 28.07.2017, EK, IS \& DH (LECB); Vsevolozhsk District, W

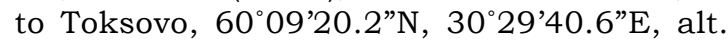
$65 \mathrm{~m}$, pine forest with Vaccinium myrtillus, $V$. vitis-idaea L., Sphagnum spp., and Polytrichum sp., on bark of Pinus sylvestris, 25.04.2016, DH \& LG (LECB). Thalli contain micareic acid. - New to LR, known from SPb (Stepanchikova et al., 2020). Distribution in North-Western European Russia outside of LR: not reported. The nearest localities in European Russia are in the Arkhangelsk Region (Tarasova et al., 2020). Distribution in Fennoscandia and Baltic countries: Sweden and Finland (Launis et al., 2019a).

Micarea laeta Launis \& Myllys - WLR, Ka, Kingisepp District, N part of Bolshoy Tuters Island (former Tytärsaari), $300 \mathrm{~m} \mathrm{SE}$ to Cape

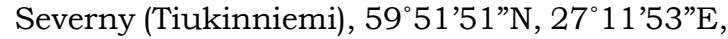
middle-aged spruce forest with single aspens (Populus tremula L.), with Vaccinium myrtillus, Maianthemum bifolium, and green mosses, on 
bark of Picea abies, 01.06.2015, IS (LECB) (published by Stepanchikova et al. (2017) as Micarea micrococca (Körb.) Gams ex Coppins). Thallus contains methoxymicareic acid. - New to LR, known from SPb (Stepanchikova et al., 2021). Distribution in North-Western European Russia outside of LR: not reported. The nearest locality in European Russia is in the Arkhangelsk Region (Tarasova et al., 2020). Distribution in Fennoscandia and Baltic countries: Sweden and Finland (Launis et al., 2019b; Kantelinen et al., 2021).

MicAReA microareolata Launis et al. - WLR, Ik, Priozersk District, N part of Konevets Island, $60^{\circ} 52^{\prime} 45^{\prime \prime} \mathrm{N}, 30^{\circ} 37^{\prime} 31^{\prime \prime} \mathrm{E}$, old-growth spruce forest with Sphagnum spp. and dwarf shrubs, on wood of Picea abies (log), 28.07.2017, EK, IS \& DH (LECB); Vsevolozhsk District, NE to Mistolovo, $60^{\circ} 08^{\prime} 13.9^{\prime \prime} \mathrm{N}, 30^{\circ} 24^{\prime} 58.0$ ” E, alt. $30 \mathrm{~m}$, birch forest with pines, with Oxalis acetosella and green mosses, on bark of Betula sp., 15.05.2016, DH \& LG (LECB) (published by Himelbrant \& Gagarina (2018) as Micarea micrococca (Körb.) Gams ex Coppins); Gatchina District, between Zhabino and Shundorovo villages, 59 $36^{\prime} 49.3^{\prime \prime} \mathrm{N}$, $29^{\circ} 36^{\prime} 41.6^{\prime \prime} \mathrm{E}$, alt. $144 \mathrm{~m}$, spruce forest with honeysuckle (Lonicera sp.), with green mosses and grasses, on bark of Betula sp., 08.09.2016, IS \& DH (LECB). Thalli contain methoxymicareic acid. - New to LR, known from SPb (Stepanchikova et al., 2020). Distribution in North-Western European Russia outside of LR: not reported. The nearest localities in European Russia are in the Arkhangelsk Region (Tarasova et al., 2020) and the Kaliningrad Region (Konoreva et al., 2020). Distribution in Fennoscandia and Baltic countries: Sweden and Finland (Launis et al., 2019b).

Micarea nowaki Czarnota \& Coppins - SPb, Petrodvorets District, Lomonosov, ca. $600 \mathrm{~m} \mathrm{~S}$ to Zavarina Str., 59 54'50.9”N, 294'02.2”E, pine forest with spruce and birch, with green mosses and Vaccinium myrtillus, on lignum of Salix caprea L., DH, IS \& Gulnara Tagirdzhanova, 20.05.2015 (LE L-12946). Thallus contains micareic acid. - New to European Russia, recently reported from Russian Caucasus (Urbanavichus et al., 2020). Distribution in Fennoscandia and Baltic countries: Finland (Myllys \& Launis, 2018), Sweden (Svensson \& Westberg, 2010).

MicAREA PUSILla Launis et al. - WLR, Ka, Kingisepp District, central part of Moschny Island (former Lavansaari), W to Taipale Isthmus, $60^{\circ} 00^{\prime} 08.4 " \mathrm{~N}, 27^{\circ} 50^{\prime} 43.1^{\prime \prime} \mathrm{E}$, black alder (Alnus glutinosa (L.) Gaertn.) forest with ferns surrounded by spruce forest, on bark of Alnus glutinosa, 20.08.2017, IS \& DH (LECB); same place, $\mathrm{N}$ shore, E to Cape Mustaniemi, $60^{\circ} 01^{\prime} 16.2^{\prime \prime} \mathrm{N}$, $27^{\circ} 50 ’ 39.8^{\prime \prime} \mathrm{E}$, seashore pine forest with sparse rowan undergrowth, with green mosses and Vaccinium myrtillus, on lignum of Pinus sylvestris, 18.08.2017, IS \& DH (LECB); Ik, Vsevolozhsk District, W to Mustajarvi Lake, $60^{\circ} 12^{\prime} 21.9^{\prime \prime} \mathrm{N}$, $30^{\circ} 35^{\prime} 20.9$ " E, alt. $83 \mathrm{~m}$, pine forest with birches, rowans, Vaccinium myrtillus, and ferns, on bark of Pinus sylvestris, 23.04.2016, DH \& LG (LECB). Thalli contain methoxymicareic acid. New to LR, known from SPb (Stepanchikova et al., 2021). Distribution in North-Western European Russia outside of LR: not reported. The nearest localities in European Russia are in the Arkhangelsk (Tarasova et al., 2020) and Kaliningrad (Konoreva et al., 2020) regions. Distribution in Fennoscandia and Baltic countries: Finland (Launis et al., 2019a).

MicAREA SORALIFERA Guzow-Krzem. et al. - WLR, $\mathrm{Ka}$, Kingisepp District, central part of Moschny Island (former Lavansaari), $\mathrm{W}$ to Taipale Isthmus, $60^{\circ} 00^{\prime} 08.4^{\prime \prime} \mathrm{N}, 27^{\circ} 50^{\prime} 43.1^{\prime \prime} \mathrm{E}$, black alder forest with ferns surrounded by spruce forest, on lignum of Picea abies, 20.08.2017, IS \& DH (LECB) (published by Stepanchikova et al. (2019) as Micarea prasina Fr. s. str.). Thallus contains micareic acid. - New to LR, known from SPb (Stepanchikova et al., 2020). Distribution in North-Western European Russia outside of LR: not reported. The nearest localities in European Russia are in the Kaliningrad Region (Konoreva et al., 2020). Distribution in Fennoscandia and Baltic countries: Sweden and Finland (Svensson et al., 2017; Myllys \& Launis, 2018).

Micarea tomentosa Czarnota \& Coppins - WLR, Ik, Priozersk District, N part of Konevets Island, $60^{\circ} 52^{\prime} 48.3$ ” N, 30³7'03.1”E, old-growth spruce forest with green mosses, dwarf shrubs, and Oxalis acetosella, on upturned roots of Picea abies, 26.07.2017, EK, IS \& DH (LECB); same place, E part of Konevets Island, SW of bay Valkoinenhiekka, 6051'32.5” $\mathrm{N}, 30^{\circ} 36^{\prime} 56.3^{\prime \prime} \mathrm{E}$, old-growth spruce forest with birch and black alder, with Sphagnum spp., Vaccinium myrtillus and patches of green mosses, on wood of Picea abies (log), 03.08.2017, EK, IS \& DH (LECB). No lichen substances detected. - New to LR, 
known from SPb (Stepanchikova et al., 2020). Distribution in North-Western European Russia outside of LR: not reported. The nearest localities in European Russia are in the Arkhangelsk Region (Tarasova et al., 2020), the Kaliningrad Region (Konoreva et al., 2020), and the Moscow Region (Muchnik et al., 2019). Distribution in Fennoscandia and Baltic countries: Sweden, Finland, Norway (Thor \& Svensson, 2008; Myllys \& Launis, 2018; Klepsland, 2020), and Estonia (Randlane et al., 2019). Micarea tomentosa can be confused with $M$. hedlundii Coppins and $M$. fennica Launis \& Myllys due to the pycnidia covered by tomentum (Czarnota, 2007). Micarea hedlundii is distinguished by the presence of Intrusa-yellow pigment in the thallus (Czarnota, 2007), and M. fennica produces micareic acid (Launis \& Myllys, 2019).

Parmelina tiliacea (Hoffm.) Hale - WLR, Luga District, Cheremenetsky Protected Area, Golubkovo village, $58^{\circ} 33^{\prime} 14.3^{\prime \prime} \mathrm{N}, 29^{\circ} 58^{\prime} 06.6^{\prime \prime} \mathrm{E}$, alt. 58 $\mathrm{m}$, old broadleaved manor park, on bark of old Tilia cordata branch, 15.05.2020, DH, AR \& IS (LECB); same place, 58 33'17.0” N, 29 $58^{\circ} 08.6^{\prime} \mathrm{E}$, alt. $52 \mathrm{~m}$, old broadleaved manor park on slope facing a lake, on bark of Corylus avellana L., 15.05.2020, DH, AR \& IS (LECB). - The first reliable record in LR. Previously reported from ELR, Staraya Ladoga (Malysheva, 2001), WLR, Koporie (Malysheva, 1999), and SPb (Weinmann, 1837), however no specimens were found in revised herbaria, and the presence of this easily identified species in the region was doubtful. Distribution in North-Western European Russia outside of LR: Republic of Karelia (Fadeeva et al., 2007), Novgorod (Kataeva, 2002) and Pskov (Istomina \& Likhacheva, 2010) regions. Distribution in Fennoscandia and Baltic countries: Norway, Sweden, and Finland (Nordin et al., 2011), Estonia (Randlane et al., 2019), Latvia (Ābolina et al., 2015), and Lithuania (Motiejūnaitè, 2017).

SClerophora PERONElla (Ach.) Tibell (Fig. 1) WLR, Luga District, Cheremenetsky Protected Area, Golubkovo village, 58 $33^{\prime} 17.0^{\prime \prime} \mathrm{N}$, $29^{\circ} 58^{\prime} 08.6^{\prime \prime} \mathrm{E}$, alt. $52 \mathrm{~m}$, old broadleaved manor park on slope to the lake, on bark of old dead Tilia cordata, 15.05.2020, DH, AR \& IS (LECB). New to LR. Distribution in North-Western European Russia outside of LR: Republic of Karelia (Fadeeva et al., 2007). Distribution in Fennoscandia and Baltic countries: Norway, Sweden, Finland (Nordin et al., 2011), Estonia (Randlane et al., 2019), Latvia (Ābolina et al., 2015), and Lithuania (Motiejūnaitè, 2017). Characterized by the pale carneous stalked apothecia with reddish-brown central core of stalk (when wet), and very small spores 3.0-3.5 $\mu \mathrm{m}$ diam. (Tibell, 1999).

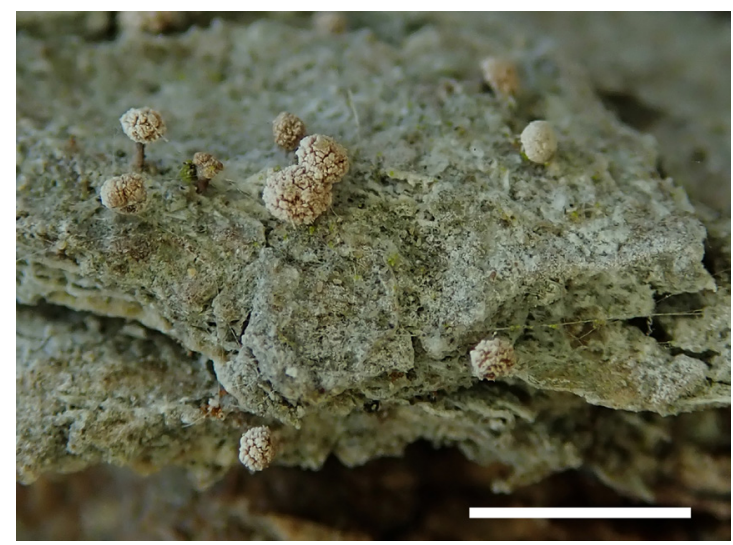

Fig. 1. Sclerophora peronella in Golubkovo manor park (LECB). Scale bar $=1 \mathrm{~mm}$.

\section{ACKNOWLEDGEMENTS}

Authors thank Ludmila V. Gagarina (Komarov Botanical Institute, Russia) and Gulnara Tagirdzhanova (University of Alberta, Canada) for participation in the field studies. We are grateful to anonymous reviewer for valuable corrections and comments. The study was carried out within the framework of the institutional research project "Flora and systematics of algae, lichens, and bryophytes of Russia and phytogeographically important regions of the world" (no. 121021600184-6) of the Komarov Botanical Institute of the Russian Academy of Sciences.

\section{REFERENCES}

Ābolinga, A., Piterāns, A. \& Bambe, B. 2015. Lichens and bryophytes in Latvia. Checklist. Salaspils, Latvijas Valsts mežzinātnes institūts "Silava", DU AA Saule. 213 pp. (In Latvian, English introduction). Alstrup, V., Zavarzin, A. A., Kocourkova, J., Kravchenko, A. V., Fadeeva, M. A. \& Shiefelbein, U. 2005. Lichens and lichenicolous fungi found in Northern Ladoga Area (Republic of Karelia) during the international field trip in August 2004, prior to the fifth Congress of International Lichenological Association: preliminary report. Proceedings of the Karelian Research Centre 7: 3-16 (In Russian, English summary). 
Brackel, W. v. 2008. Phoma ficuzzae sp. nov. and some other lichenicolous fungi from Sicily, Italy. Sauteria 15: 103-120.

Brackel, W. v. 2014. Kommentierter Katalog der flechtenbewohnenden Pilze Bayerns. Bibliotheca Lichenologica 109: 1-476.

Czarnota, P. 2007. The lichen genus Micarea (Lecanorales, Ascomycota) in Poland. Polish Botanical Studies 23: 1-199.

Diederich, P., Lawrey, J. D. \& Ertz, D. 2018. The 2018 classification and checklist of lichenicolous fungi, with 2000 non-lichenized, obligately lichenicolous taxa. The Bryologist 121(3): 340-425: 340-426. https://doi.org/10.1639/0007-2745-121.3.340

Fadeeva, M. A., Golubkova, N. S., Vitikainen, O. \& Ahti, T. 2007. Conspectus of lichens and lichenicolous fungi of the Republic of Karelia. Petrozavodsk. 194 pp. (In Russian, English summary).

Guzow-Krzemińska, B., Czarnota, P., Łubek, A. \& Kukwa, M. 2016. Micarea soralifera sp. nov., a new sorediate species in the $M$. prasina group. The Lichenologist 48(3): 161-169. https://doi. org/10.1017/S0024282916000050

Hawksworth, D. L. \& Cole, M. S. 2002. Intralichen, a new genus for lichenicolous 'Bispora' and 'Trimmatostoma' species. Fungal Diversity 11: 87-97.

Himelbrant, D. E. \& Gagarina, L. V. 2018. Lichens of the provisional protected area "Toksovsky" and vicinities (Leningrad Region). Vestnik Tverskogo gosudarstvennogo universiteta. Seriya "Biologia i ekologiya" 1: 151-170. (In Russian, English summary).

Himelbrant, D. \& Kuznetsova, E. 2002. Lignicolous lichens on driftwood of the Keret' archipelago (White Sea). Botanika Lithuanica 8(4): 349-355.

Himelbrant, D. E., Stepanchikova, I. S., Kuznetsova, E. S., Motiejūnaitè, J. \& Konoreva, L. A. 2018. Konevets Island (Leningrad Region, Russia) a historical refuge of lichen diversity in Lake Ladoga. Folia Cryptogamica Estonica 55: 51-78. https://doi.org/10.12697/fce.2018.55.07

Himelbrant, D. E., Stepanchikova, I. S., Motiejūnaitè, J., Gerasimova, J. V., Kuznetsova, E. S., Dyomina, A. V. \& Tsurykau, A. G. 2017. New records of lichens and allied fungi from the Leningrad Region, Russia. VIII. Folia Cryptogamica Estonica 54: 6370. https:// doi.org/10.12697/fce.2017.54.11

Himelbrant, D. E., Stepanchikova, I. S., Motiejūnaite, J., Kuznetsova, E. S., Tagirdzhanova, G. \& Frolov, I. V. 2019. New records of lichens and allied fungi from the Leningrad Region, Russia. X. Folia Cryptogamica Estonica 56: 23-29. https://doi. org/10.12697/fce.2019.56.04

Himelbrant, D. E., Stepanchikova, I. S., Motiejūnaitè, J., Vondrak, J., Tagirdzhanova, G. M., Gagarina, L. V. \& Kuznetsova, E. S. 2015. New records of lichens and allied fungi from the Leningrad Region, Russia. VI. Folia Cryptogamica Estonica 52: 21-28. https://doi.org/10.12697/fce.2015.52.03

Intralichen baccisporus. British Lichen Society 2021. https://www.britishlichensociety.org.uk/re- sources/species-accounts/intralichen-baccisporus (24 March 2021).

Istomina, N. B. \& Likhacheva, O. V. 2010. The preliminary list of lichens of the Pskov Region (Russia). Novosti sistematiki nizshikh rastenii 44: 171-199. (In Russian, English summary). https://doi. org/10.31111/nsnr/2010.44.171

Kantelinen, A., Westberg, M., Owe-Larsson, B. \& Svensson, M. 2021. New Micarea records from Norway and Sweden and an identification key to the M. prasina group in Europe. Graphis Scripta 33(2): 17-28.

Kataeva, O. A. 2002. Annotated list of lichens of the Novgorod Region. Novosti sistematiki nizshikh rastenii 36: 114-143. (In Russian).

Klepsland, J. T. 2020. Thirty lichens and lichenicolous fungi new to Norway. Graphis Scripta 32(7): 120-143.

Konoreva, L. A., Chesnokov, S. V., Korolev, K. S. \& Himelbrant, D. E. 2020. On the Micarea prasina group (Pilocarpaceae) in the Kaliningrad Region. Novosti sistematiki nizshikh rastenii 54(2): 429-440. https://doi.org/10.31111/ nsnr/2020.54.2.429

Kotiranta, H., Uotila, P., Sulkava, S. \& Peltonen, S.-L. (eds). 1998. Red Data Book of East Fennoscandia. Helsinki. $351 \mathrm{pp}$.

Kukwa, M., Himelbrant, D. E. \& Kuznetsova, E. S. 2003. New records of Lepraria from Russia. Botanika Lithuanica 9(3): 259-264.

Kuznetsova, E., Ahti, T. \& Himelbrant, D. 2007. Lichens and allied fungi of the Eastern Leningrad Region. Norrlinia 16: 1-62.

Kuznetsova, E. S., Motiejūnaitè, J., Stepanchikova, I. S., Himelbrant, D. E. \& Czarnota, P. 2012. New records of lichens and allied fungi from the Leningrad Region, Russia. III. Folia Cryptogamica Estonica 49: 31-37. https://doi.org/10.12697/ fce.2013.50.07

Launis, A. \& Myllys, L. 2019. Micarea fennica, a new lignicolous lichen species from Finland. - Phytotaxa 409: 179-188. https://doi.org/10.11646/ phytotaxa.409.3.6

Launis, A., Malǐček, J., Svensson, M., Tsurykau, A., Sérusiaux, E. \& Myllys, L. 2019a. Sharpening species boundaries in the Micarea prasina group, with a new circumscription of the type species $M$. prasina. Mycologia 111(4): 574-592. https://doi. org/10.1080/00275514.2019.1603044

Launis, A., Pykälä, J., Boom, P. van den, Sérusiaux, E. \& Myllys, L., 2019b. Four new epiphytic species in the Micarea prasina group from Europe. The $L i-$ chenologist 51(1): 7-25. https://doi.org/10.1017/ S0024282918000555

Lawrey, J. D. \& Diederich, P. 2018. Lichenicolous fungi - worldwide checklist, including isolated cultures and sequences available. http://www. lichenicolous.net (25 March 2021).

Makarova, I. I. \& Himelbrant, D. E. 2008. Family Stereocaulaceae Cevall. Handbook of the lichens of 
Russia. Issue 10. Nauka, St. Petersburg: 443-463. (In Russian).

Malysheva, N. V. 1999. The plants of medieval fortresses in the North-West Russia. 1. Fortresses in the Leningrad Region. Botanicheskii Zhurnal 84(10): 46-59. (In Russian, English summary).

Malysheva, N. V. 2001. The lichens of the museumreserve Staraya Ladoga (Leningrad Region). Novosti sistematiki nizshikh rastenii 35: 171-178. (In Russian).

Motiejūnaitè, J. 2017. Supplemented checklist of lichens and allied fungi of Lithuania. Botanica Lithuanica 23(2): 89-106. https://doi.org/10.1515/ botlit-2017-0011

Motiejūnaitè, J., Chesnokov, S. V., Czarnota, P., Gagarina, L. V., Frolov, I., Himelbrant, D., Konoreva, L. A., Kubiak, D., Kukwa, M., Moisejevs, R., Stepanchikova, I., Suija, A., Tagirdzhanova, G., Thell, A. \& Tsurykau, A. 2016. Ninety-one species of lichens and allied fungi new for Latvia with a list of additional records from Kurzeme. Herzogia 29(1): 143-163. https://doi.org/10.13158/ heia.29.1.2016.143

Muchnik, E. E., Konoreva, L. A., Chesnokov, S. V., Paukov, A. G., Tsurykau, A. \& Gerasimova, J. V. 2019. New and otherwise noteworthy records of lichenized and lichenicolous fungi from central European Russia. Herzogia 32(1): 111-126. https://doi.org/10.13158/heia.32.1.2019.111

Musyakova, V. V. \& Himelbrant, D. E. 1998. Macrolichens in vicinities of University Station "Priladozhskaya". Vestnik Sankt-Peterburgskogo Universiteta. Series 3 (Biologiya) 1: 44-49. (In Russian).

Myllys, L. \& Launis, A. 2018. Additions to the diversity of lichens and lichenicolous fungi living on decaying wood in Finland. Graphis Scripta 30(6): 7887.

Nordin, A., Moberg, R., Tønsberg, T., Vitikainen, O., Dalsätt, Å., Myrdal, M., Snitting, D. \& Ekman, S. 2011. Santesson's Checklist of Fennoscandian Lichen-forming and Lichenicolous Fungi. Ver. April 29, 2011 - http://130.238.83.220/santesson/ home.php (1 March 2021).

Orange, A., James, P. W. \& White, F. J. 2001. Microchemical methods for the identification of lichens. London. $101 \mathrm{pp}$.

Randlane, T., Saag, A. \& Suija, A. 2019. Lichenized, lichenicolous and allied fungi of Estonia. Ver. December 31, 2019 - http://esamba.bo.bg.ut.ee/ checklist/est/home.php (27 March 2021).

Rettig, J. 2016. Zum Vorkommen flechtenbewohnender Pilze in Ostthüringen. Herzogia 29: 730-744. https://doi.org/10.13158/heia.29.2.2016.730

Sérusiaux, E., Diederich, P., Ertz, D. \& van den Boom, P. P. G. 2003. New or interesting lichens and lichenicolous fungi from Belgium, Luxembourg and Northern France. IX. Lejeunia N. S. 173: 1-48.

Smith, C. W., Aptroot, A., Coppins, B. J., Fletcher, A., Gilbert, O. L., James, P. W. \& Wolseley, P. A. (eds).
2009. The Lichens of Great Britain and Ireland. The British Lichen Society, London. 1046 pp.

Stepanchikova, I. S., Andreev, M. P., Himelbrant, D. E., Motiejūnaitè, J., Schiefelbein, U., Konoreva, L. A. \& Ahti, T. 2017. The lichens of Bolshoy Tuters Island (Tytärsaari), Leningrad Region, Russia. Folia Cryptogamica Estonica 54: 95-116. https:/ / doi.org/10.12697/fce.2017.54.14

Stepanchikova, I. S., Himelbrant, D. E., Kuznetsova, E. S., Chesnokov, S. V., Konoreva, L. A. \& Pankova, V. V. 2021. The lichens of Pukhtolova Gora (St. Petersburg, Russia). Folia Cryptogamica Estonica 58: 73-86. https://doi.org/10.12697/ fce. 2021.58 .10

Stepanchikova, I. S., Himelbrant, D. E., Kuznetsova, E. S., Motiejūnaitè, J., Chesnokov, S. V., Konoreva, L. A. \& Gagarina, L. V. 2020. The lichens of the northern shore of the Gulf of Finland in the limits of St. Petersburg, Russia - diversity on the edge of megapolis. Folia Cryptogamica Estonica 57: 101132. https://doi.org/10.12697/fce.2020.57.11

Stepanchikova, I. S., Himelbrant, D. E., Motiejūnaitè, J., Ahti, T., Suja, A., Kuznetsova, E. S. \& Dyomina, A. V. 2018. New records of lichens and allied fungi from the Leningrad Region, Russia. IX. Folia Cryptogamica Estonica 55: 117-124. https:/ / doi. org/ 10.12697 / fce.2018.55.12

Stepanchikova, I. S., Himelbrant, D. E., Schiefelbein, U., Motiejūnaitè, J., Ahti, T. \& Andreev, M. P. 2019. The lichens of Moshchny Island (Lavansaari) - one of the remote islands in the Gulf of Finland. Folia Cryptogamica Estonica 56: 31-52. https://doi.org/10.12697/fce.2019.56.05

Stepanchikova, I. S., Kukwa, M., Kuznetsova, E. S., Motiejūnaitè, J. \& Himelbrant, D. E. 2010. New records of lichens and allied fungi from the Leningrad Region. Folia Cryptogamica Estonica 47: 7784.

Suija, A., Zhurbenko, M. P., Stepanchikova, I. S., Himelbrant, D. E., Kuznetsova, E. S. \& Motiejūnaitè, J. 2020. Kukwaea pubescens gen. et $s p$. nova (Helotiales, incertae sedis), a new lichenicolous fungus on Cetraria islandica, and a key to the lichenicolous fungi occurring on Cetraria s. str. Phytotaxa 459(1): 39-50. https:// doi.org/10.11646/phytotaxa.459.1.4

Svensson, M. \& Westberg, M. 2010. Additions to the lichen flora of Fennoscandia. Graphis Scripta 22(2): 33-37.

Svensson, M., Ekman, S., Klepsland, J. T., Nordin, A., Thor, G., von Hirschheydt, G., Jonsson, F., Knutsson, T., Lif, M., Spribille, T. \& Westberg, M. 2017. Taxonomic novelties and new records of Fennoscandian crustose lichens. MycoKeys 25: 51-86. https://doi.org/10.3897/ mycokeys.25.13375

Tarasova, V. N., Konoreva, L. A., Zhurbenko, M. P., Pystina, T. N., Chesnokov, S. V., Androsova, V. I., Sonina, A. V., Semenova, N. A. \& Valekzhanin, A. A. 2020. New and rare lichens and allied fungi from Arkhangelsk Region, North-West Russia. 
Folia Cryptogamica Estonica 57: 85-100. https:// doi.org/10.12697/fce.2020.57.10

Thor, G. \& Svensson, M. 2008. Micarea tomentosa new to Sweden. Graphis Scripta 20(1): 28-30.

Tibell, L. 1999. Calicioid lichens and fungi. Nordic Lichen Flora. Vol. 1. Nordic Lichen Society, Bonuslän '5, Uddevalla, pp. 20-94.

Urbanavichus, G., Vondrák, J., Urbanavichene, I., Palice, Z. \& Maliček, J. 2020. Lichens and allied non-lichenized fungi of virgin forests in the Caucasus State Nature Biosphere Reserve (Western Caucasus, Russia). Herzogia 33(1): 90-138. https://doi.org/10.13158/heia.33.1.2020.90

Weinmann J. A. 1837. Enumeratio Stirpium In Agro Petropolitano Sponte Crescentium: Secundum Systema Sexuale Linneanum Composita. Petropoli. 320 pp. 